\title{
Maintaining experiences of nature as a city grows
}

\author{
$\underline{\text { Jessica R. Sushinsky }}^{1,2}, \underline{\text { Jonathan R. Rhodes }}^{2,3} \underline{\text { Danielle F. Shanahan }}^{2,4}, \underline{\text { Hugh P. Possingham }}^{2,5}$ and Richard A. Fuller $^{2}$
}

\begin{abstract}
Experiences of nature contribute to human health and well-being, yet as the world's population continues to concentrate in towns and cities there is mounting concern that these experiences are diminishing. Despite this, little is known about how we can maintain experiences of nature as cities grow. Here, we quantify how people's opportunities to experience nature might change with future urban growth in the city of Brisbane, Australia. We simulated the addition of 84,642 houses under compact and sprawling growth scenarios and modeled changes in people's opportunities to experience nature by estimating changes in backyard size, public green space provision, and bird species richness close to households. We discovered that the form of urban growth could strongly influence people's opportunities to experience nature in a way that is highly nonrandom across the socioeconomic gradient. Under a sprawling pattern of development, with low residential densities and few interstitial green spaces, our models suggest severe declines in access to public green space and bird species richness around people's homes. These declines are predicted to be concentrated in socioeconomically disadvantaged areas of the city. Compact development leads to greater reductions in backyard size, but smaller declines in access to public green space and bird species richness. Our results point to a difficult trade-off; residential infill will maintain larger green spaces and higher overall bird diversity but reduce backyard sizes, impacting people's opportunities to experience nature in a different way. Careful planning is needed to balance the availability of public and private urban green spaces to ensure that the opportunities for people to experience nature are maintained as urbanization continues.
\end{abstract}

Key Words: backyards; biodiversity conservation; Brisbane, Australia; green space; human well-being; socioeconomic status; urban biodiversity; urban ecology; urban growth

\section{INTRODUCTION}

People have an inherent need for contact with nature, and experiences of the natural world provide a range of benefits to human health and well-being (Wilson 1984, Brown and Grant 2005, Tidball 2012, Keniger et al. 2013, Hough 2014). However, because the majority of the world's population now lives in towns and cities, there is mounting concern that experiences of nature are becoming fewer in number and poorer in quality, constituting an extinction of experience (Pyle 1978, Turner et al. 2004, Louv 2005, Miller 2005, Stokes 2006). Net human population growth is now occurring almost entirely within towns and cities (United Nations 2011), and as cities continue to increase in density and population size around the world we risk deepening the extinction of experience and adversely affecting human health and wellbeing. We estimate how opportunities to experience nature might be affected by alternative urban growth strategies, using the city of Brisbane, Australia as a case study.

The health and well-being benefits associated with experiences of nature range from psychological, cognitive, and physiological to social, spiritual, and tangible (Irvine and Warber 2002, Bird 2004, 2007, Brown and Grant 2005, Maller et al. 2005, Barton and Pretty 2010, Keniger et al. 2013). Interactions with local wildlife can underpin cultural and personal identity (Horwitz et al. 2001, Russ et al. 2015), help people feel more vigorous and self-aware (Henwood 2003), and contribute to psychological well-being (Bird 2007, Fuller et al. 2007). Green spaces within cities are also associated with wider social benefits such as diminished crime, violence, and aggression (Sullivan and Kuo 1996, Kuo and Sullivan 2001, Aldridge and Sempik 2002). City residents use parks and gardens for restoration and relaxation (Ulrich et al. 1991, Korpela et al. 2001, Hartig et al. 2003, MacKerron and
Mourato 2013), exercise (Bird 2004), and to engage in social interactions (Coley et al. 1997, Herzog et al. 1997, Sullivan et al. 2004; Kaźmierczak 2013). Human health and well-being is inextricably linked to experiences of nature and as health problems in cities rise (Dye 2008) there is a critical need to improve people's access to nature.

How people access and experience nature in cities is complex with several geographic and societal factors involved. Public parks and gardens and green streetscapes (public green spaces) serve as sites for interaction with nature in people's daily lives (Pyle 2003, Miller 2006, Campbell et al. 2016, Hartig and Kahn 2016). Backyards (private green spaces) also provide spaces for people to experience nature in a manner that is distinct from those experiences in public green space (Fuller and Irvine 2010, Shanahan et al. 2014). Public and private green spaces also help promote healthy biodiversity throughout the city (Gagné and Fahrig 2010, Aronson et al. 2014, Villaseñor et al. 2017), which helps to provide interaction with nature in people's daily lives. Thus, an accessible network of public and private green spaces throughout a city is important for regular access to nature (Giles-Corti et al. 2005, Cohen et al. 2010, Schipperijn et al. 2010). Social factors such as age, gender, and education also influence how people access nature (Ho et al. 2005, Lin et al. 2014, Pleson et al. 2014), and socioeconomically disadvantaged areas often have lower quality and quantity of public green spaces (Wen et al. 2013, Astell-Burt et al. 2014, Kellert et al. 2017), vegetative cover (Iverson and Cook 2000, Tooke et al. 2010, Pham et al. 2012, Shanahan et al. 2014), and species richness (Kinzig et al. 2005, Strohbach et al. 2009, van Heezik et al. 2013). With so many factors influencing how people access nature in cities it is unlikely that all people have the same opportunities to experience nature in cities and these differences

\footnotetext{
${ }^{1}$ Americas Program, Wildlife Conservation Society, Fort Collins, Colorado, United States, ${ }^{2}$ School of Biological Sciences, The University of Queensland, Brisbane, Queensland, Australia, ${ }^{3}$ School of Earth and Environmental Sciences, The University of Queensland, Brisbane, Queensland, Australia, ${ }^{4}$ Zealandia Sanctuary, Wellington, New Zealand, ${ }^{5}$ The Nature Conservancy, South Brisbane, Queensland, Australia
} 
have the potential to either exacerbate disadvantage or, where managed effectively, contribute to equity (Heynen et al. 2006).

Managing and improving people's access to nature has become a priority for many cities (Sandström et al. 2009). Often this involves planting trees, greening streetscapes, improving the quality of green spaces, ensuring all residents have public green spaces near their homes, and sometimes biodiversity conservation efforts. However, most cities are also experiencing very rapid growth and while the importance of access to nature for people's health and well-being is well understood, it remains unknown how experiences of nature could change in quantity and quality as cities grow. Given the pace and extent of urban growth around the world understanding how development decisions impact people's experiences of nature is critical to safeguarding the associated health and well-being benefits to society.

We explore the implications for people's access to nature of perhaps the most significant planning decision that needs to be made as a city grows; the extent to which it uses compact and sprawling forms of development (Lin and Fuller 2013, Sushinsky et al. 2013, Soga et al. 2014, Stott et al. 2015). Compact development retains large green spaces between high-density residential neighborhoods and sprawling development spreads lower residential densities neighborhoods across a large area often with fewer interstitial green spaces for a given human population size. Compact development may be beneficial for biodiversity at larger scales by maintaining a robust network of large, intact green spaces (Sushinsky et al. 2013, Beninde et al. 2015, Ikin et al. 2015), but will often have detrimental effects on biodiversity at the local scale by replacing vegetation with dense built form (Chace and Walsh 2006, Tratalos et al. 2007, McDonnell et al. 2009, Vergnes et al. 2014). We might expect that while biodiversity will benefit from compact development at the city scale, the opportunity to experience nature around the home might decline. This is due to the reduction in the sizes of private yards (Hall 2010), which are areas for nature experiences close to home (Barbosa et al. 2007, Forman 2008) and can also provide habitat for species (Rudd et al. 2002, Daniels and Kirkpatrick 2006, Irvine et al. 2009, Goddard et al. 2010).

Here, we quantify the impact of compact and sprawling urban growth on opportunities to experience nature by measuring changes in backyard size, public green space provision, and bird species richness as a city grows. We use Brisbane, Australia, as a case study, a rapidly growing subtropical city with an extensive system of green spaces and high biological diversity. We estimate changes in opportunities to experience nature under a compact mode of development where new housing is exclusively accommodated by subdividing existing residential plots, thus leaving the public green space network intact, and a sprawling form of growth where new housing is placed exclusively on developable green spaces. We modeled how people's access to nature will change under the two forms of urban growth by measuring changes in (i) backyard size, (ii) the amount of public green space close to households, and (iii) bird species richness close to households. Finally, we determined which socioeconomic groups within the city will be most affected by changes in access to nature close to home.

\section{METHODS}

We first developed a current land use map and models of the current distributions of bird species across the city. We then projected these forward under two alternative urban growth scenarios to estimate how backyard size, public green space provision, and bird species richness close to where people live could change as the city grows. Last, we examined how predicted changes in people's access to nature were related to current measures of socioeconomic status. To focus our analysis on primarily residential areas we estimated changes in backyard size, public green space provision, and bird species richness only for suburbs in the study area with a minimum of 20 residential properties $(n=165)$.

\section{Study area}

Greater Brisbane currently supports a population of 2.07 million, and is growing rapidly with a population increase of $11.5 \%$ between 2006 and 2011 (Australian Government Bureau of Statistics 2011). The state government plans to add 156,000 houses to the city by 2031 (Queensland Department of Infrastructure and Planning 2009). Our study area covered 636 $\mathrm{km}^{2}$ of the city and was defined by contiguous $1 \mathrm{~km}^{2}$ grid cells that were (i) within Brisbane's administrative boundary, and (ii) at least $25 \%$ urbanized (as judged by eye from aerial imagery). We limited the extent of the study area to the urbanized portion of the city in this way because Brisbane's administrative boundary includes large areas of nonurban land cover. The study area ensured various land use types and degrees of urbanization were well represented.

\section{Land use}

We developed a land use map for the study area using a digitized, spatially referenced cadastral dataset containing the property boundaries and description for all land parcels in Queensland (Queensland Government Department of Environment and Resource Management 2006) and the Queensland Valuation and Sales dataset (QVAS), which provides the statutory valuations of land parcels in Queensland (Queensland Government Department of Environment and Resource Management 2006). Both datasets are from 2006. Using these datasets we created a unified land use data layer in which each property in the cadastral dataset was classified into one of five categories and then verified using Google Earth aerial imagery from 2007:

- Residential: All properties with at least one dwelling and/or any associated properties that are used for private yards.

- Urban: Urban infrastructure comprising impervious surfaces such as roads, commercial buildings, and shopping centers.

- Protected green space: All properties classified by QVAS as "parks and gardens" and all other conservation reserves.

- Developable green space: All areas covered by vegetation without the QVAS classification of "parks and gardens," including areas that are undeveloped and do not have formal conservation status or significant amenity value.

- Water: All areas covered by mostly water, including the Brisbane River as well as streams, lakes, and reservoirs. 


\section{Bird distributions}

We used models of 36 species' distributions taken from Sushinsky et al. (2013) to estimate current bird species richness near the home across the study area. The models were based on a total of 636 bird surveys in the urban area of Brisbane performed during the spring breeding season of 2009, between 25 August and 11 November. We collected data on the presence of bird species across the city by conducting five-minute point counts at each survey point during which all species encountered were listed. The resulting dataset comprised 7986 observations of 119 species, and models were built for all 36 bird species that had at least 15 occurrence records. We used Maxent (Phillips and Dudík 2008) to construct species distribution models as functions of six selected environmental variables (land use, dwelling density, vegetative cover, vegetative heterogeneity, temperature, precipitation, and distance to the city periphery) on a $200 \mathrm{~m} \times 200$ $\mathrm{m}$ grid across the city. The logistic output from Maxent equates to a probability that the species will be observed in each $200 \mathrm{~m}$ pixel, given the environmental conditions that exist there (Phillips and Dudík 2008). Analyses of bird distributions were conducted at a $200 \mathrm{~m}$ resolution because we expected detectability to be approximately limited to $200 \mathrm{~m}$ and this resolution is fine enough to adequately capture the heterogeneity in land cover across the urban landscape.

\section{Urban growth scenarios}

We developed scenarios of compact and sprawling urban growth based on current development patterns, projected population growth in Brisbane, and the city's plans to accommodate that growth. The scenarios were implemented on an individual property scale using the land use data layer described above. In the compact scenario, housing density is increased through infill and subdivision of existing residential areas. In Brisbane, developers typically subdivide a residential property by purchasing single-dwelling plots, demolishing the existing house, and building multiple residential units, each occupying only a portion of the original lot. The sprawling scenario directs low density development to areas of open space outside already developed areas (areas covered by vegetation without any significant amenity value), a continuation of the pattern of urban growth in Brisbane over the past few decades. In each scenario a total of 84,642 dwellings were added to the study area; this is an area-weighted proportion of the 156,000 dwellings that Brisbane City Council is expected to accommodate by 2031, according to the Southeast Queensland Regional Plan 2009 (Queensland Government Department of Infrastructure and Planning 2009). The spatial extent of the city was not increased in either scenario because we are comparing alternative patterns of expansion within the city boundary.

To reflect compact growth, existing single-dwelling properties with an area of at least half that of the median single-dwelling property size for each suburb were considered suitable for subdivision. Such properties were randomly selected, subdivided, and developed one at a time, rotating through all suburbs in random sequence, until 84,642 dwellings had been added to the study area. The number of subdivisions within each plot was based on the empirical relationships between plot size and the number of dwellings for all of the existing subdivided properties across Brisbane. This relationship was calculated for high, medium, and low density suburbs (low density: $y=0.81 x-1.67$, $r^{2}=0.674, P<0.001$; medium density: $y=0.68 x-1.3, r^{2}=0.632$, $P<0.001$; high density: $\left.y=0.64 x-1.13, r^{2}=0.580, P<0.001\right)$, and plots within each suburb were subdivided according to the regression for that particular density category. For the sprawling scenario new single dwelling properties were added to developable green spaces. Developable green spaces with an area of at least half that of the median single-dwelling property within each suburb were considered suitable for development. Developable green spaces with an area greater than 1.5 times that of the median single-dwelling property size (per suburb) were prepared for development by dividing each space into rectangular plots with an area equal to that of the median single-dwelling property size within the suburb. Developable properties were then randomly selected and developed into single-dwelling properties one at a time, rotating through all suburbs in random sequence, until 84,642 dwellings were added to the study area. In practice, other factors such as flood risk, slope, or city regulations mandating that green spaces are set aside in new developments might limit the area that is developed (for full details on development of the urban growth scenarios see Sushinsky et al. 2013).

\section{Change in backyard size}

We estimated backyard size for each residential property in the study area under current conditions and for both the compact and sprawling scenarios using the land use data layer we developed. Change in backyard size was estimated at the suburb level because the addition of new residential properties is the source of change and so measuring change in backyard size at the individual property level is not possible. Buildings are not mapped across Brisbane so we built linear regression models predicting backyard size from total property area using random samples of 300 single-dwelling $\left(y=1.2 x-0.76 x, r^{2}=0.977, P<0.001\right)$ and 300 multidwelling properties $\left(y=1.28 x-1.14, r^{2}=0.866, P<\right.$ $0.001)$. We then used these regression relationships to estimate backyard size from property size for each residential property in the city under current conditions and for both the compact and sprawling urban growth scenarios after all houses were added to the study area. We calculated average backyard size per dwelling for each suburb in the study area. We then calculated the proportional change in the average backyard size per dwelling for each suburb in the study area (the difference between current and future average backyard size per dwelling divided by the current average backyard size per dwelling).

\section{Change in public green space}

We calculated the amount of public green space within the immediate neighborhood of the home on a per property basis under current conditions and for both the compact and sprawling scenarios using the land use data layer we developed. Change in public green space provision around the home was modeled for a random sample of 29,091 residential properties $(10 \%$ or a minimum of 20 residential properties from each suburb) that were not subject to development under either urban growth scenario to directly measure changes experienced by dwellers of households that persisted through the development. Changes in public green space were calculated directly from the land use data layer we developed. In the compact scenario only existing residential properties were developed and so there was no change in the land use classification across the study area (i.e., no change in the amount of public green space in the city). However, in the sprawling scenario green space was converted to residential land 
use, which resulted in residential land use increasing while public green space decreased over time.

We defined access to public green space as the total area within a $500 \mathrm{~m}$ radius (originating from the center of the property) of each sampled residential property comprising parks and public gardens, conservation reserves, or any other mostly vegetated surface (including developable green spaces that were not designated as parks and gardens or conservation reserves). The amount of public green space within $500 \mathrm{~m}$ of the home is the local government's accessibility standard for local recreational green space in urban areas (Brisbane City Council 2000) and this standard is supported by an analysis in Lin et al. (2014), which showed that the area covered by public parks within $500 \mathrm{~m}$ of the home significantly influences park use by Brisbane city residents. After all houses were added to the study area under the sprawling urban growth scenario we calculated the proportional change in the total public green space area within $500 \mathrm{~m}$ of each sampled residential property (the difference between current and future total public green space area divided by the current total public green space area). We then calculated the mean proportional change in the amount of public green space per residential property for each suburb for both urban growth scenarios

\section{Change in bird species richness around the home}

We projected the current bird distribution models forward in Maxent (Phillips and Dudík 2008) according to the expected changes in the environmental variables (land use, dwelling density, vegetative cover, and vegetative heterogeneity) under the two development scenarios (for full details on the development and validation of the current and projected species' distribution models see Sushinsky et al. 2013). The changes in the environmental variables were calculated based on the changes in the land use map. For current conditions and for the compact and sprawling development scenarios we predicted the presence or absence of each species per $200 \mathrm{~m}$ pixel across the study area by applying a threshold that balanced omission and commission error rates (Liu et al. 2005) to the habitat suitability estimates for each species.

Using the species' presence/absence predictions and the same random sample of residential properties used to model changes in green space provision we estimated bird species richness within a $500 \mathrm{~m}$ radius of each sampled residential property under current conditions and for both the compact and sprawling urban growth scenarios. For each of the randomly sampled residential properties we calculated bird species richness as the sum of species' presences (across all 36 species) inside a $500 \mathrm{~m}$ buffer originating at the center of the property. We selected the $500 \mathrm{~m}$ radius as a reasonable area in which people might interact with bird species in private and public areas around the home. The center of any $200 \mathrm{~m}$ pixel (from the bird distribution models) had to be within the $500 \mathrm{~m}$ buffer for its value to contribute to the total richness estimate for the buffer. We calculated the proportional change in bird species richness (the difference between current and projected species richness divided by current species richness) within a $500 \mathrm{~m}$ radius of each of the randomly sampled residential properties. We then calculated the mean proportional change in species richness per residential property for each suburb for both urban growth scenarios.
Change in access to nature and the socioeconomic gradient We used a socioeconomic index from the 2006 Australian Census (IRSAD; Index of Relative Socioeconomic Advantage and Disadvantage) in which higher values indicate areas of relatively high advantage (Australian Government Bureau of Statistics 2006). It is calculated using a number of variables such as education level, income, and access to services. For each suburb across the study area we calculated the mean IRSAD value. Under each growth scenario we tested for correlations between IRSAD and changes in backyard size, public green space provision around the home, and species richness around the home at the suburb level using Spearman's correlation coefficient. We explored the relationship between the IRSAD index and the spatial distribution of new residential growth by testing for correlations between IRSAD and the total number of new dwellings added per suburb for each growth scenario using Spearman's correlation coefficient.

\section{RESULTS}

Backyard size and provision of public green space and species richness around the home all changed under both the compact and sprawling development scenarios but the magnitude as well as the spatial and socioeconomic distribution of the changes varied considerably between the scenarios. At the city scale almost all metrics of people's opportunities to experience nature suffered declines under both development scenarios (only public green space provision under compact development remained unchanged). With sprawling development average backyard size per dwelling declined by $0.03 \%(\mathrm{SE}=3.63, \mathrm{n}=385,281)$, area covered by public green space within $500 \mathrm{~m}$ of the home declined by an average of $17.85 \%(\mathrm{SE}=0.15, \mathrm{n}=29,091)$, and species richness within $500 \mathrm{~m}$ of the home declined by an average of $3.74 \%$ ( $\mathrm{SE}=0.04, \mathrm{n}=29,091$; Fig. 1). Under compact development average backyard size per dwelling declined by $3.45 \%$ ( $\mathrm{SE}=4.40$, $\mathrm{n}=300,639$ ), there was no change in the area covered by public green space within $500 \mathrm{~m}$ of the home, and species richness within $500 \mathrm{~m}$ of the home declined by an average of $0.82 \%$ ( $\mathrm{SE}=0.02$, $\mathrm{n}=29,091$; Fig. 1). Sprawling development resulted in a negligible decline in backyard size but larger declines in public green space provision and species richness around the home while compact development resulted in a larger decline in backyard size but smaller declines in public green space provision and species richness around the home.

The spatial distribution of changes in people's access to nature was another important difference between the compact and sprawling development scenarios. Under compact development average backyard size per dwelling declined (between $0.0002 \%$ and $23.17 \%$ ) in all suburbs across the study area, however, with sprawling development just $35 \%$ of suburbs experienced declines (between $0.02 \%$ and $53.63 \%$ ) in average backyard size per dwelling, and $65 \%$ suburbs experienced an increase or no change in average backyard size per dwelling (Fig. 2). With compact development just $5 \%$ of the suburbs experienced a decline of more than $5 \%$ in average backyard size per dwelling while $16 \%$ of the suburbs experienced a decline of more than $5 \%$ in average backyard size per dwelling with sprawling development (Fig. 2). The degree of decline was relatively evenly spread throughout the city with compact development but with sprawling development the largest declines tended to concentrate along the outer edges of the city (Fig. 2). Overall, while compact development resulted 
Fig. 1. Changes in people's opportunities to experience nature under compact and sprawling urban growth scenarios; (a) proportional change in mean backyard size $\left(\mathrm{m}^{2}\right)$ per dwelling, (b) mean proportional change in the total area covered by public green space within a 500 meter radius of the home, and (c) mean proportional change in bird species richness within a 500 meter radius of the home. Data are means \pm standard error; for green space cover and bird species richness standard errors were too small to visualize.

(a)

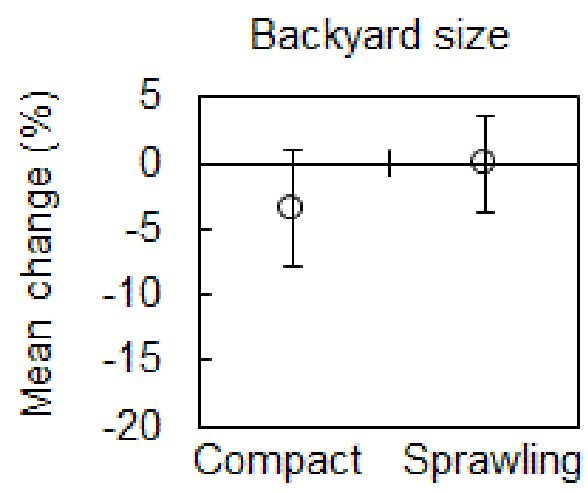

(b)

Green space cover

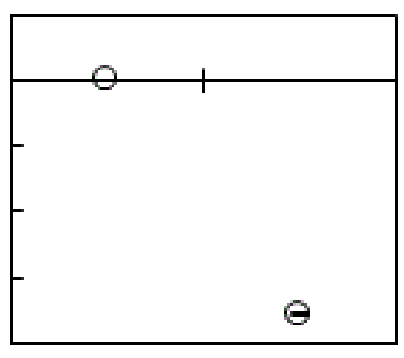

(c)

\section{Bird species richness}

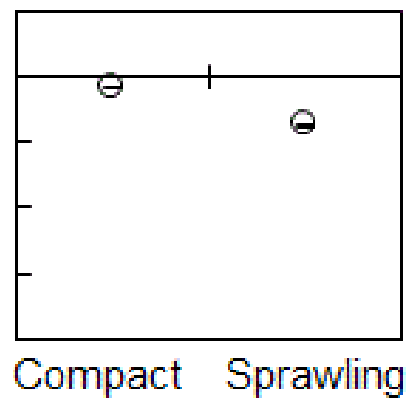

in declines in average backyard size per dwelling across the entire city the declines were smaller in magnitude and more evenly distributed across the city than with sprawling development (Fig. 2).

Provision of public green space around the home sharply declined across the study area with sprawling development (Fig. 3). Residential development under compact urban growth did not require development of public green space, however, $59 \%$ of the developable green space around the city was converted to residential land use under sprawling urban growth. With sprawling development there was a decline in the mean area of public green space within $500 \mathrm{~m}$ of the home in $94 \%$ of the suburbs with the remaining $6 \%$ of the suburbs experiencing no change in public green space provision (Fig. 3). In $73 \%$ of the suburbs the

Fig. 2. Proportional change in mean backyard size $\left(\mathrm{m}^{2}\right)$ per dwelling for each suburb in the study area for (a) compact and (b) sprawling urban growth scenarios. Suburbs with a mean increase or no change in backyard size are colored dark to light green while suburbs with a mean decrease in backyard size are colored light to dark red.

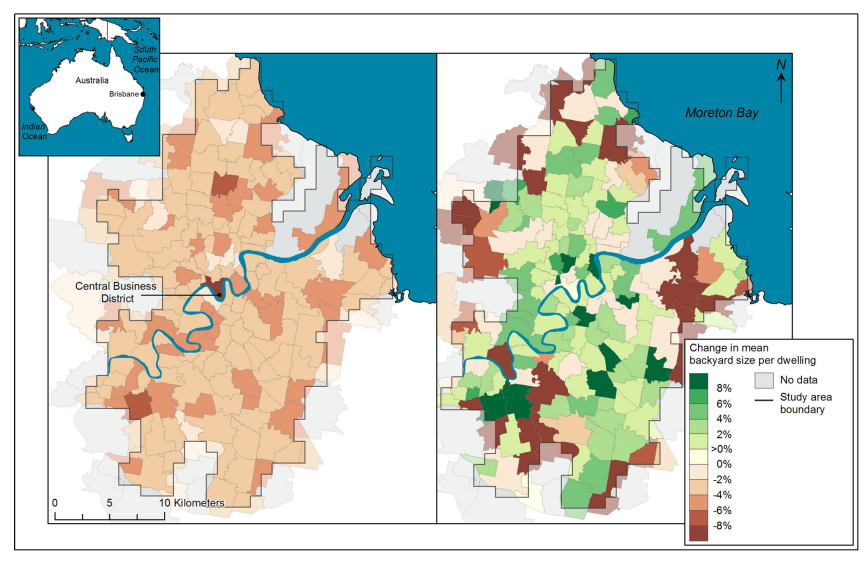

Fig. 3. Mean proportional change in the total area covered by public green space $\left(\mathrm{m}^{2}\right)$ within a 500 meter radius of the home for each suburb across the city under the sprawling urban growth scenario. There was no change in the amount of green space in the city between the current scenario and the future compact development scenario so no data are shown for the compact development scenario. Suburbs with a mean increase or no change in public green space area within 500 meters of the home are colored dark to light green while suburbs with a mean decrease in public green space area within 500 meters of the home are colored light to dark red.

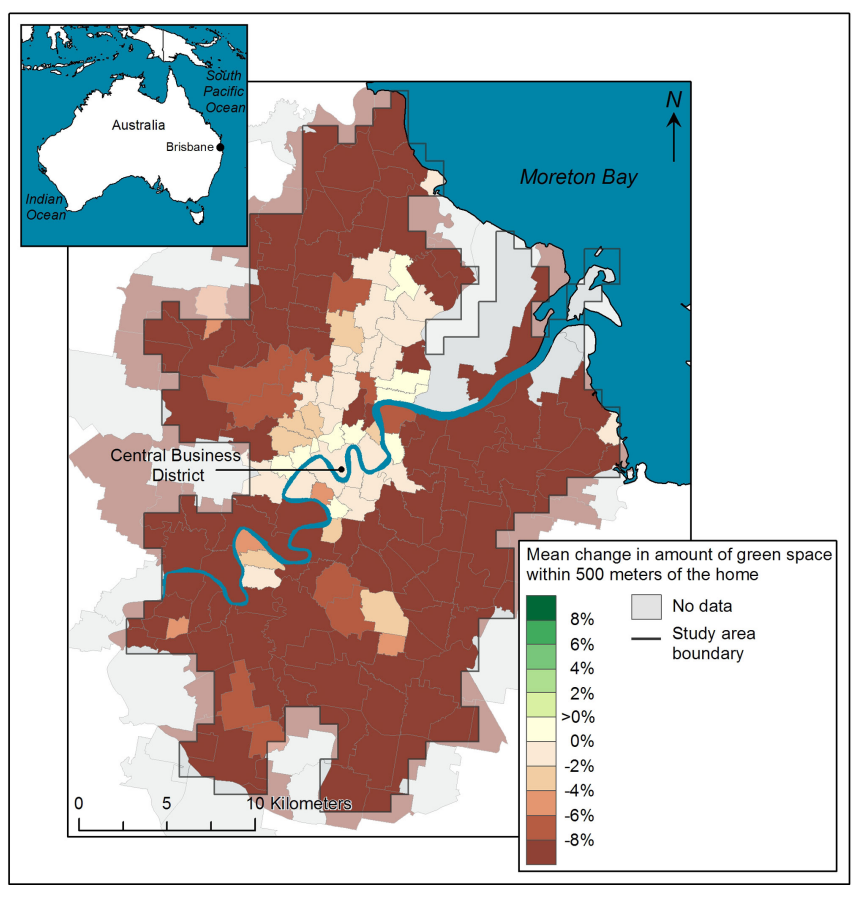


average decline in the amount of green space within $500 \mathrm{~m}$ of the home was more than $5 \%$ and in $60 \%$ of the suburbs the average decline in green space provision around the home was more than $10 \%$ (Fig. 3). The largest declines in average green space provision around the home were concentrated around the outer edges of the city and along the river (Fig. 3) where there is the most developable green space. The sprawling development scenario requires the development of green spaces resulting in considerable declines in public green space provision around the home for city residents, however, the compact development scenario accommodates the same residential growth without changing public green space provision around homes.

Under both urban growth scenarios there were changes in species richness around the home, but the magnitude and spatial heterogeneity of these changes were much less pronounced under compact development (Fig. 4). With compact development the majority of suburbs $(56 \%)$ had a mean decrease of less than $2 \%$ in species richness within $500 \mathrm{~m}$ of the home and approximately $26 \%$ of suburbs had a mean proportional increase or no change in species richness around the home (Fig. 4a). This is in sharp contrast to sprawling development where the majority of suburbs (61\%) showed a mean decline of $2 \%$ or more, and just $7 \%$ of suburbs had a mean proportional increase or no change in species richness around the home (Fig. 4b). Furthermore, the largest declines in species richness around the home were concentrated along the outer edges of the city under sprawling development (Fig. 4b) and these outer suburbs also experience the most severe declines in the amount of public green space around the home (Fig. 3). Although there were declines in species richness around the home under both development scenarios, species richness around the home declined less rapidly and showed a more even spatial pattern with compact development (Fig. 4).

As well as being spatially variable, changes in public green space provision and species richness were spread inequitably along the socioeconomic gradient under sprawling urban development. With sprawling development there was a significant positive correlation between the mean proportional change in public green space area within $500 \mathrm{~m}$ of the home (per suburb) and the IRSAD index $(r=0.145, n=165, p=0.032$; Fig. 5a illustrates the mean declines in public green space across socioeconomic groups). There was also a significant positive correlation between the mean proportional change in bird species richness within $500 \mathrm{~m}$ of the home (per suburb) and the IRSAD index $(r=0.144, n=165, p$ $=0.032$; Fig. $5 \mathrm{~b}$ ) with sprawling development. This is in sharp contrast to compact development under which there was no significant correlation between the IRSAD index and mean proportional changes in species richness around the home ( $\mathrm{r}$ $=-0.026, n=165, p=0.370)$. Changes in backyard size were not related to the socioeconomic gradient; there was no significant correlation between proportional change in mean backyard size per dwelling and IRSAD under either compact $(\mathrm{r}=-0.012, \mathrm{n}=$ $165, \mathrm{p}=0.066)$ or sprawling $(\mathrm{r}=-0.019, \mathrm{n}=165, \mathrm{p}=0.405)$ development. Thus, the more disadvantaged sectors of the city will experience greater declines in both public green space and species richness around the home under sprawling development and while compact development resulted in declines in backyard size these changes are not related to the socioeconomic gradient.
Fig. 4. Mean proportional change in bird species richness within a 500 meter radius of the home for each suburb in the study area for (a) compact and (b) sprawling urban growth scenarios. Suburbs with a mean increase or no change in species richness within 500 meters of the home are colored dark to light green while suburbs with a mean decrease in species richness within 500 meters of the home are colored light to dark red.

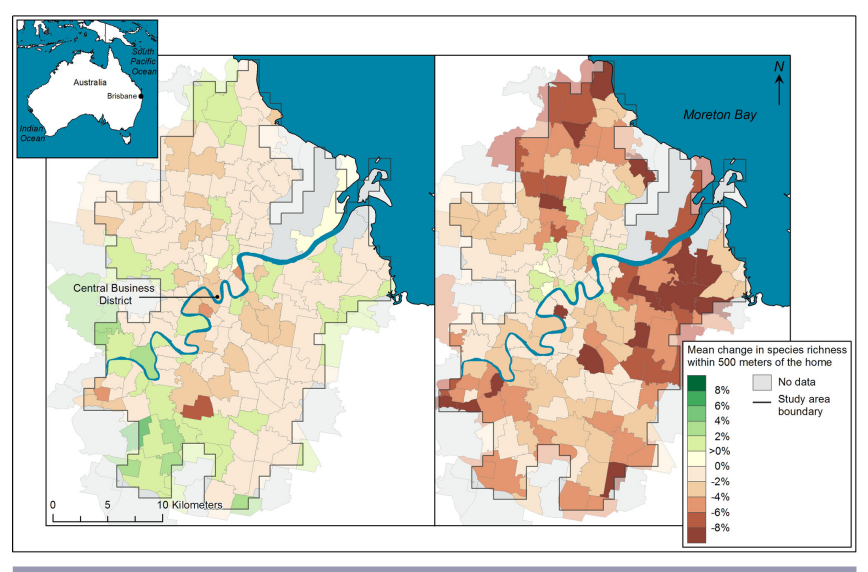

The concentration of greater declines in people's access to nature in socioeconomically disadvantaged areas of the city may be related to the spatial distribution of new residential growth under sprawling urban development; we found a significant negative correlation between the total number of new dwellings added (per suburb) and the IRSAD index $(r=-0.1966, n=165, p=0.005)$ under sprawling development but no correlation with compact development $(\mathrm{r}=-0.0338, \mathrm{n}=165, \mathrm{p}=0.333)$. Overall, our results suggest that compact development better maintains people's experiences of nature as the city grows, and also helps ensure that any reductions are evenly distributed across the socioeconomic gradient.

\section{DISCUSSION}

Our analysis is the first attempt to quantify changes in people's opportunities to experience nature under alternative urban growth strategies. We show that the form of urban growth could have an important impact on changes in access to nature experienced by city residents. Although both compact and sprawling urban growth result in a reduction in people's opportunities to experience nature, our models predict that while sprawling growth retains larger backyards on average there are severe declines in bird species richness and provision of public green space around the home with the more disadvantaged areas of the city being particularly affected. These results suggest policies that encourage carefully planned compact development could help to minimize declines in people's opportunities to experience nature around the home, at least in a currently low density city such as Brisbane. Further work is needed to explore how these results might generalize more widely. 
Fig. 5. The relationship between socioeconomic status, as measured by the Index of Relative Socioeconomic Advantage and Disadvantage (IRSAD) and the proportional decline in (a) total area covered by green space within a 500 meter radius of the home and (b) bird species richness within a 500 meter radius of the home for compact (triangles) and sprawling (circles) urban growth scenarios. There was no change in the amount of green space in the city between the current scenario and the future compact development scenario so no data are shown for the compact development scenario. Data are means \pm standard error. (a)

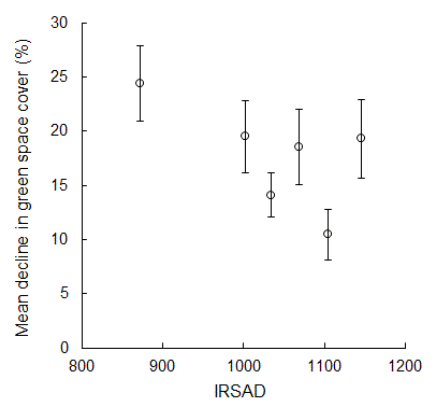

(b)

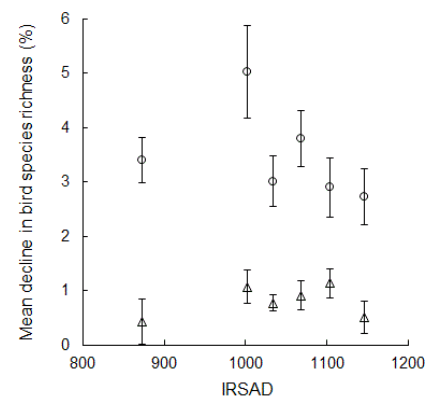

People's access to nature in cities is often related to socioeconomic status, with more disadvantaged areas often having lower overall vegetation cover (Iverson and Cook 2000, Tooke et al. 2010, Pham et al. 2012) and species richness (Strohbach et al. 2009, van Heezik et al. 2013). In Brisbane, tree cover is positively correlated with socioeconomic status implying that people who live in socioeconomically disadvantaged areas already have reduced access to nature (Shanahan et al. 2014). In our study we found that less advantaged areas experience greater declines in public green space and species richness around the home under sprawling development. There is a growing body of evidence showing that experiences of local biodiversity enhance health and well-being (Fuller et al. 2007, Mitchell and Popham 2008, Grinde and Patil 2009) and disadvantaged areas are generally associated with lower levels of health and well-being (Davey-Smith et al. 1990, 1997, Bartley et al. 1997, Brunner 1997). Sprawling growth therefore has the potential to widen the gap between advantaged and disadvantaged sectors of society, and can therefore be considered a public health issue.

There are several potential mechanisms driving the relationship between socioeconomic status and changes in people's access to nature. For example, the spatial distribution of residential growth might be crucial; under sprawling development we found a significant negative correlation between the total number of new dwellings added (per suburb) and socioeconomic status, while there was no correlation under compact development. Sprawling development requires developable green space for new residential development and in Brisbane this results in new residential development being concentrated in areas of the city of lower socioeconomic status, often situated on the outskirts of the city. Under compact development new residential growth does not require developable green space and can be more evenly spread throughout the city. Ultimately, the loss of these developable green spaces under sprawling development resulted in larger declines in public green space and species richness around the home in areas of lower socioeconomic status.

The role of compact urban growth in maintaining people's experiences with nature depends crucially on retaining high quality interstitial green spaces between high density residential developments. Green spaces help minimize the environmental impacts of urban growth by maintaining a more ecologically heterogeneous city, which in turn supports higher species richness at the city scale (Bryant 2006, Sandström et al. 2006, Sushinsky et al. 2013). Thus, residential development must be carefully planned to ensure that residents of high density areas maintain suitable access to local green spaces (Burton 2000).

Although compact urban growth may indeed be best for minimizing changes in people's access to nature in a growing city there are potential negative effects that must be considered. First, bird species that are most sensitive to urban development will decline regardless of urban growth form (Sushinsky et al. 2013, Soga et al. 2014, Stott et al. 2015), and once residential density reaches a certain critical threshold one would expect almost all species to decline as vegetation cover reaches very low levels (Tratalos et al. 2007, Evans et al. 2009). Second, a reduction in the size of private backyards inevitably accompanies an increase in housing density if this is delivered through residential infill (Hall 2010), which may limit people's interactions with species around the home. Interaction with nature in public green spaces is not necessarily a substitute for such interactions in backyards (Barbosa et al. 2007, Forman 2008). Finally, recent research shows that people in areas of low residential density use public green spaces more frequently and are more satisfied with the green space areas than people in areas of higher residential densities (Soga et al. 2015). Thus, careful management is needed to balance access to both backyards and public green spaces as cities grow. At the least it seems critical to include efforts to improve the ecological quality of backyards (e.g., Bryant 2006, Smith et al. 2006a,b, Gaston et al. 2007, Hostetler and Drake 2009, Goddard et al. 2010) when increasing housing density to help mitigate declines in sensitive bird species, any reduction in backyard size, and people's potential lack of use or satisfaction with public green space.

As the human population continues to become concentrated into towns and cities, more people will be exposed to the extinction of experience and the health risks associated with living in cities. The health and well-being benefits associated with interaction with nature may help to mitigate some of these health risks for city residents. Thus, it is crucial to consider how people's access to nature will change and how we can minimize any changes as we grow our cities. Our analysis suggests that the form of urban growth can have profound impacts on how people's experiences with nature change and how changes in people's access to nature are distributed across the socioeconomic gradient. We can help maintain and possibly even improve connection to nature in cities and perhaps avoid widening the gap between advantaged and disadvantaged sectors of society by building higher density residential areas in the spaces between high quality green spaces across the city. 
Responses to this article can be read online at:

http://www.ecologyandsociety.org/issues/responses. php/9454

\begin{abstract}
Acknowledgments:
We are grateful to Adrian Bannister, Margot Drewe, Scott McKinnon, and Steven Sushinsky for their assistance with data collection, Chris Lepczyk and Paige Warren for comment and discussion, and Tony K. Gill for the development of data which was essential to the analysis. This work was funded through ARC Discovery grants DP120102857 and DP130100218, a University of Queensland Research Scholarship to J.R.S., an ARC Future Fellowship to R.A.F., and an ARC Laureate Fellowship to H.P.P. Additional funding support was provided by the Australian Government's National Environmental Research Program and the Australian Research Council Centre of Excellence for Environmental Decisions.
\end{abstract}

\section{LITERATURE CITED}

Aldridge, J., and J. Sempik. 2002. Social and therapeutic horticulture: evidence and messages from research. Loughborough University, Centre for Child and Family Research, Leicestershire, UK.

Aronson, M. F. J., F. A. La Sorte, C. H. Nilon, M. Katti, M. A. Goddard, C. A. Lepczyk, P. S. Warren, N. S. G. Williams, S. Cilliers, B. Clarkson, C. Dobbs, R. Dolan, M. Hedblom, S. Klotz, J. L. Kooijmans, I. Kühn, I. MacGregor-Fors, M. McDonnell, U. Mörtberg, P. Pyšek, S. Siebert, J. Sushinsky, P. Werner, and M. Winter. 2014. A global analysis of the impacts of urbanization on bird and plant diversity reveals key anthropogenic drivers. Proceedings of the Royal Society B 281(1780). http://dx.doi. org/10.1098/rspb.2013.3330

Astell-Burt, T., X. Feng, S. Mavoa, H. M. Badland, and B. GilesCorti. 2014. Do low-income neighbourhoods have the least green space? A cross-sectional study of Australia's most populous cities. BMC Public Health 14(292):292-302. http://dx.doi. org/10.1186/1471-2458-14-292

Australian Government Bureau of Statistics. 2006. Socioeconomic indexes for areas. (SEIFA) Technical Paper. Australian Government Bureau of Statistics, Canberra, Australia.

Australian Government Bureau of Statistics. 2011. 2011 Australian census. Australian Government Bureau of Statistics, Canberra, Australia.

Barbosa, O., J. A. Tratalos, P. R. Armsworth, R. G. Davies, R. A. Fuller, P. Johnson, and K. J. Gaston. 2007. Who benefits from access to green space? A case study from Sheffield, UK. Landscape and Urban Planning 83(2-3):187-195. http://dx.doi.org/10.1016/j. landurbplan.2007.04.004

Bartley, M., D. Blane, and S. Montgomery. 1997. Socioeconomic determinants of health: health and the life course: why safety nets matter. British Medical Journal 314(7088):1194-1203. http://dx. doi.org/10.1136/bmj.314.7088.1194
Barton, J., and J. Pretty. 2010. Urban ecology and human health and wellbeing. Pages 202-229 in K. J. Gaston, editor. Urban ecology. Cambridge University Press, New York, New York, USA. http://dx.doi.org/10.1017/CBO9780511778483.010

Beninde, J., M. Veith, and A. Hochkirch. 2015. Biodiversity in cities needs space: a meta-analysis of factors determining intraurban biodiversity variation. Ecology Letters 18(6):581-592. http://dx.doi.org/10.1111/ele.12427

Bird, W. 2004. Natural fit: can green space and biodiversity increase levels of physical activity? Royal Society for the Protection of Birds, Sandy, UK.

Bird, W. 2007. Natural thinking: investigating the links between the natural environment, biodiversity and mental health. Royal Society for the Protection of Birds, Sandy, UK.

Brisbane City Council. 2000. City plan 2000. Brisbane City Council, Brisbane, Australia.

Brown, C., and M. Grant. 2005. Biodiversity and human health: what role for nature in healthy urban planning? Built Environment 31(4):326-338. http://dx.doi.org/10.2148/benv.2005.31.4.326

Brunner, E. 1997. Socioeconomic determinants of health: stress and the biology of inequality. British Medical Journal 314 (7092):1472-1485. http://dx.doi.org/10.1136/bmj.314.7092.1472

Bryant, M. M. 2006. Urban landscape conservation and the role of ecological greenways at local and metropolitan scales. Landscape and Urban Planning 76(1-4):23-44. http://dx.doi. org/10.1016/j.landurbplan.2004.09.029

Burton, E. 2000. The compact city: just or just compact? A preliminary analysis. Urban Studies 37(11):1969-2006. http://dx. doi.org/10.1080/00420980050162184

Campbell, L. K., E. S. Svendsen, N. F. Sonti, and M. L. Johnson. 2016. A social assessment of urban parkland: analyzing park use and meaning to inform management and resilience planning. Environmental Science and Policy 62:34-44. http://dx.doi. org/10.1016/j.envsci.2016.01.014

Chace, J. F., and J. J. Walsh. 2006. Urban effects on native avifauna: a review. Landscape and Urban Planning 74(1):46-49. http://dx.doi.org/10.1016/j.landurbplan.2004.08.007

Cohen, D. A., T. Marsh, S. Williamson, K. P. Derose, H. Martinez, C. Setodji, and T. L. McKenzie. 2010. Parks and physical activity: why are some parks used more than others? Preventive Medicine 50(S):S9-S12. http://dx.doi.org/10.1016/j.ypmed.2009.08.020

Coley, R. L., W. C. Sullivan, and F. E. Kuo. 1997. The social context created by nature in urban public housing. Environment and Behavior 29(4):468-494. http://dx.doi.org/10.1177/00139165$\underline{9702900402}$

Daniels, G. D., and J. B. Kirkpatrick. 2006. Does variation in garden characteristics influence conservation of birds in suburbia? Biological Conservation 133(3):326-335. http://dx.doi. org/10.1016/j.biocon.2006.06.011

Davey-Smith, G., C. Hart, D. Blane, C. Gillis, and V. Hawthrone. 1997. Lifetime socioeconomic position and mortality: prospective observational study. British Medical Journal 314(7086):547-565. http://dx.doi.org/10.1136/bmj.314.7080.547 
Davey-Smith, G., M. J. Shipley, and G. Rose. 1990. The magnitude and causes of socioeconomic differentials in mortality: further evidence from the Whitehall study. Journal of Epidemiology and Community Health 44(4):260-265.

Dye, C. 2008. Health and urban living. Science 319 (5864):766-769. http://dx.doi.org/10.1126/science.1150198

Evans, K. L., S. E. Newson, and K. J. Gaston. 2009. Habitat influences on urban avian assemblages. Ibis 151(1):19-39. http:// dx.doi.org/10.1111/j.1474-919X.2008.00898.X

Forman, R. T. T. 2008. Urban regions: ecology and planning beyond the city. Cambridge University Press, New York, New York, USA. http://dx.doi.org/10.1017/CBO9780511754982

Fuller, R. A., and K. N. Irvine. 2010. Interactions between people and nature in urban environments. Pages 134-171 in K. J. Gaston, editor. Urban ecology. Cambridge University Press, New York, New York, USA. http://dx.doi.org/10.1017/CBO9780511778483.008

Fuller, R. A., K. N. Irvine, P. Devine-Wright, P. H. Warren, and K. J. Gaston. 2007. Psychological benefits of green space increase with biodiversity. Biology Letters 3(4):390-394. http://dx.doi. org/10.1098/rsbl.2007.0149

Gagné, S. A., and L. Fahrig. 2010. The trade-off between housing density and sprawl area: minimising impacts to forest breeding birds. Basic and Applied Ecology 11(8):723-733. http://dx.doi. org/10.1016/j.baae.2010.09.001

Gaston, K. J., P. Cush, S. Ferguson, P. Frost, S. Gaston, D. Knight, A. Loram, R. M. Smith, K. Thompson, and P. H. Warren. 2007. Improving the contribution of urban gardens for wildlife: some guiding propositions. British Wildlife 18(3):171-177.

Giles-Corti, B., M. H. Broomhall, M. Knuiman, C. Collins, K. Douglas, K. Ng, A. Lange, and R. J. Donovan. 2005. Increasing walking: how important is distance to, attractiveness, and size of public open space? American Journal of Preventive Medicine 28 (2):169-176. http://dx.doi.org/10.1016/j.amepre.2004.10.018

Goddard, M. A., A. J. Dougill, and T. G. Benton. 2010. Scaling up from gardens: biodiversity conservation in urban environments. Trends in Ecology and Evolution 25(2):90-98. http:// dx.doi.org/10.1016/j.tree.2009.07.016

Grinde, B., and G. G. Patil. 2009. Biophilia: Does visual contact with nature impact on health and well-being? International Journal of Environmental Research and Public Health 6 (9):2332-2343. http://dx.doi.org/10.3390/ijerph6092332

Hall, T. 2010. The life and death of the Australian backyard. CSIRO Publishing, Collingwood, Australia.

Hartig, T., G. W. Evans, L. D. Jamner, D. S. Davis, and T. Gärling. 2003. Tracking restoration in natural and urban field settings. Journal of Environmental Psychology 23(2):109-123. http://dx.doi. org/10.1016/S0272-4944(02)00109-3

Hartig, T., and P. H. Kahn Jr. 2016. Living in cities, naturally. Science 352(6288):938-940. http://dx.doi.org/10.1126/science. aaf3759

Henwood, K. 2003. Is there a role for environmental and countryside agencies in promoting benefits to health? NHS Health Development Agency, London, UK.
Herzog, T. R., A. M. Black, K. A. Fountaine, and D. J. Knotts. 1997. Reflection and attentional recovery as distinctive benefits of restorative environments. Journal of Environmental Psychology 17(2):165-170. http://dx.doi.org/10.1006/jevp.1997.0051

Heynen, N., H. A. Perkins, and P. Roy. 2006. The political ecology of uneven urban green space: the impact of political economy on race and ethnicity in producing environmental inequality in Milwaukee. Urban Affairs Review 42(1):3-25. http://dx.doi. org/10.1177/1078087406290729

Ho, C. H., V. Sasidharan, W. Elmendorf, F. K. Willits, A. R. Graefe, and G. Godbey. 2005. Gender and ethnic variations in urban park preferences, visitation, and perceived benefits. Journal of Leisure Research 37(3):281-306.

Horwitz, P., M. Lindsay, and M. O’Connor. 2001. Biodiversity, endemism, sense of place, and public health: Inter-relationships for Australian inland aquatic systems. Ecosystem Health 7 (4):253-265. http://dx.doi.org/10.1046/j.1526-0992.2001.01044.x

Hostetler, M., and D. Drake. 2009. Conservation subdivisions: a wildlife perspective. Landscape and Urban Planning 90 (3-4):95-101. http://dx.doi.org/10.1016/j.landurbplan.2008.10.018

Hough, R. L. 2014. Biodiversity and human health: evidence for causality? Biodiversity and Conservation 23(2):267-288. http://dx. doi.org/10.1007/s10531-013-0614-1

Ikin, K., D. S. Roux, L. Rayner, N. R. Villaseñor, K. Eyles, P. Gibbons, A. D. Manning, and D. B. Lindenmayer. 2015. Key lessons for achieving biodiversity-sensitive cities and towns. Ecological Management \& Restoration 16(3):206-214. http://dx. doi.org/10.1111/emr.12180

Irvine, K. N., P. Devine-Wright, S. R. Payne, R. A. Fuller, B. Painter, and K. J. Gaston. 2009. Green space, soundscape, and urban sustainability: an interdisciplinary, empirical study. Local Environment 14(2):155-172. http://dx.doi.org/10.1080/13549830802522061

Irvine, K. N., and S. L. Warber. 2002. Greening healthcare: practicing as if the natural environment really mattered. Alternative Therapies 8(5):76-83.

Iverson, L. R., and E. A. Cook. 2000. Urban forest cover of the Chicago region and its relation to household density and income. Urban Ecosystems 4(2):105-124. http://dx.doi.org/10.1023/ A:1011307327314

Kaźmierczak, A. 2013. The contribution of local parks to neighbourhood social ties. Landscape and Urban Planning 109 (1):31-44. http://dx.doi.org/10.1016/j.landurbplan.2012.05.007

Kellert, S. R., D. J. Case, D. Escher, D. J. Witter, J. MikelsCarrasco, and P. T. Seng. 2017. The nature of Americans: disconnection and recommendations for reconnection. DJ Case \& Associates, Mishawaka, Indiana, USA.

Keniger, L. E., K. J. Gaston, K. N. Irvine, and R. A. Fuller. 2013. What are the benefits of interacting with nature? International Journal of Environmental Research and Public Health 10 (3):913-935. http://dx.doi.org/10.3390/ijerph10030913

Kinzig, A. P., P. Warren, C. Martin, D. Hope, and M. Katti. 2005. The effects of human socioeconomic status and cultural characteristics on urban patterns of biodiversity. Ecology and Society 10(1):23. http://dx.doi.org/10.5751/ES-01264-100123 
Korpela, K. M., T. Hartig, F. G. Kaiser, and U. Fuhrer. 2001. Restorative experience and self-regulation in favorite places. Environment and Behavior 33(4):572-589. http://dx.doi. org/10.1177/00139160121973133

Kuo, F. E., and W. C. Sullivan. 2001. Environment and crime in the inner city: Does vegetation reduce crime? Environment and Behavior 33(3):343-367. http://dx.doi.org/10.1177/0013916501333002

Lin, B. B., and R. A. Fuller. 2013. Sharing or sparing? How should we grow the world's cities? Journal of Applied Ecology 50 (5):1161-1168. http://dx.doi.org/10.1111/1365-2664.12118

Lin, B. B., R. A. Fuller, R. Bush, K. J. Gaston, and D. F. Shanahan. 2014. Opportunity or orientation? Who uses urban parks and why. PLOS ONE 9(1):e87422. http://dx.doi.org/10.1371/journal. pone. 0087422

Liu, C., P. M. Berry, T. P. Dawson, and R. G. Pearson. 2005. Selecting thresholds of occurrence in the prediction of species distributions. Ecography 28(3):385-393. http://dx.doi.org/10.1111/ j.0906-7590.2005.03957.x

Louv, R. 2005. Last child in the woods: saving our children from nature-deficit disorder. Algonquin Books, Chapel Hill, North Carolina, USA.

MacKerron, G., and S. Mourato. 2013. Happiness is greater in natural environments. Global Environmental Change 23 (5):992-1000. http://dx.doi.org/10.1016/j.gloenvcha.2013.03.010

Maller, C., M. Townsend, A. Pryor, P. Brown, and L. St Leger. 2005. Health nature healthy people: 'contact with nature' as an upstream health promotion intervention for populations. Health Promotion International 21(1):45-54. http://dx.doi.org/10.1093/ heapro/dai032

McDonnell, M. J., A. K. Hahs, and J. H. Breuste, editors. 2009. Ecology of cities and towns: a comparative approach. Cambridge University Press, New York, New York, USA. http://dx.doi. org/10.1017/CBO9780511609763

Miller, J. R. 2005. Biodiversity conservation and the extinction of experience. Trends in Ecology and Evolution 20(8):430-434. http:// dx.doi.org/10.1016/j.tree.2005.05.013

Miller, J. R. 2006. Restoration, reconciliation, and reconnecting with nature nearby. Biological Conservation 127(3):356-361. http://dx.doi.org/10.1016/j.biocon.2005.07.021

Mitchell, R., and F. Popham. 2008. Effect of exposure to natural environment on health inequalities: an observational population study. Lancet 372(9650):1655-1660. http://dx.doi.org/10.1016/ $\underline{\mathrm{S} 0140-6736(08) 61689-\mathrm{X}}$

Pham, T.-T.-H., P. Apparicio, A.-M. Séguin, S. Landry, and M. Gagnon. 2012. Spatial distribution of vegetation in Montreal: an uneven distribution of environmental inequity? Landscape and Urban Planning 107(3):214-224. http://dx.doi.org/10.1016/j. landurbplan.2012.06.002

Phillips, S. J., and M. Dudík. 2008. Modeling of species distributions with Maxent: new extensions and a comprehensive evaluation. Ecography 31(2):161-175. http://dx.doi.org/10.1111/ j.0906-7590.2008.5203.x
Pleson, E., L. M. Nieuwendyk, K. K. Lee, A. Chaddah, C. I. J. Nykiforuk, and D. Schopflocher. 2014. Understanding older adults' usage of community green spaces in Taipei, Taiwan. International Journal of Environmental Research and Public Health 11(2):1444-1464. http://dx.doi.org/10.3390/ijerph110201444

Pyle, R. M. 1978. The extinction of experience. Horticulture 56:64-67.

Pyle, R. M. 2003. Nature matrix: reconnecting people and nature. Oryx 37(2):206-214. http://dx.doi.org/10.1017/S0030605303000383

Queensland Government Department of Environment and Resource Management. 2006. Digital cadastral database. Queensland Government Department of Environment and Resource Management, Brisbane, Queensland, Australia.

Queensland Government Department of Infrastructure and Planning. 2009. South East Queensland Regional Plan 2009-2031. Queensland Department of Infrastructure and Planning, Brisbane, Queensland, Australia.

Rudd, H., J. Vala, and V. Schaefer. 2002. Importance of backyard habitat in a comprehensive biodiversity conservation strategy: a connectivity analysis of urban green spaces. Restoration Ecology 10(2):368-375. http://dx.doi.org/10.1046/j.1526-100X.2002.02041. $\underline{\mathrm{X}}$

Russ, A., S. J. Peters, M. E. Krasny, and R. C. Stedman. 2015. Development of ecological place meaning in New York City. Journal of Environmental Education 46(2):73-93. http://dx.doi. org/10.1080/00958964.2014.999743

Sandström, U. G. 2009. Urban green spaces for human wellbeing. In Impact assessment and human wellbeing, 29th Annual Conference of the International Association for Impact Assessment, Ghana. International Association for Impact Assessment, Ghana.

Sandström, U. G., P. Angelstam, and G. Mikusiński. 2006. Ecological diversity of birds in relation to the structure of urban green space. Landscape and Urban Planning 77(1-2):39-53. http:// dx.doi.org/10.1016/j.landurbplan.2005.01.004

Schipperijn, J., U. K. Stigsdotter, T. B. Randrup, and J. Troelsen. 2010. Influences on the use of urban green space - a case study in Odense, Denmark. Urban Forestry \& Urban Greening 9(1):25-32. http://dx.doi.org/10.1016/j.ufug.2009.09.002

Shanahan, D. F., B. B. Lin, K. J. Gaston, R. Bush, and R. A. Fuller. 2014. Socio-economic inequalities in access to nature on public and private lands: a case study from Brisbane, Australia. Landscape and Urban Planning 130:14-23. http://dx.doi. org/10.1016/j.landurbplan.2014.06.005

Soga, M., Y. Yamaura, T. Aikoh, Y. Shoji, T. Kubo, and K. J. Gaston. 2015. Reducing the extinction of experience: association between urban form and recreational use of public green space. Landscape and Urban Planning 143:69-75. http://dx.doi. org/10.1016/j.landurbplan.2015.06.003

Soga, M., Y. Yamaura, S. Koike, K. J. Gaston. 2014. Land sharing vs. land sparing: does the compact city reconcile urban development and biodiversity conservation? Journal of Applied Ecology 51(5):1378-1386. http://dx.doi.org/10.1111/1365-2664.12280 
Smith, R. M., K. J. Gaston, P. H. Warren, and K. Thompson. 2006a. Urban domestic gardens (VIII): environmental correlates of invertebrate abundance. Biodiversity Conservation 15 (8):2515-2445. http://dx.doi.org/10.1007/s10531-005-2784-y

Smith, R. M., K. J. Gaston, P. H. Warren, K, Thompson, and P. H. Warren. 2006b. Urban domestic gardens (VI): environmental correlates of invertebrate abundance. Biodiversity Conservation 15(8):2415-2438. http://dx.doi.org/10.1007/s10531-004-5014-0

Stokes, D. L. 2006. Conservators of experience. BioScience 56 (1):6-7. http://dx.doi.org/10.1641/0006-3568(2006)056[0007:COE] 2.0. $\mathrm{CO} ; 2$

Stott, I., M. Soga, R. Inger, and K. J. Gaston. 2015. Land sparing is crucial for urban ecosystem services. Frontiers in Ecology and the Environment 13(7):387-393. http://dx.doi.org/10.1890/140286

Strohbach, M. W., D. Haase, and N. Kabisch. 2009. Birds and the city: urban biodiversity, land use, and socioeconomics. Ecology and Society 14(2):31. http://dx.doi.org/10.5751/ES-03141-140231

Sullivan, W. C., and F. E. Kuo. 1996. Do trees strengthen urban communities, reduce domestic violence? Aborist News 5:33-34.

Sullivan, W. C., F. E. Kuo, and S. F. DePooter. 2004. The fruit of urban nature: vital neighbourhood spaces. Environmental and Behavior 36(5):678-700. http://dx.doi.org/10.1177/0193841X04264945

Sushinsky, J. R., J. R. Rhodes, H. P. Possingham., T. K. Gill, and R. A. Fuller. 2013. How should we grow cities to minimize their biodiversity impacts? Global Change Biology 19(2):401-410. http://dx.doi.org/10.1111/gcb.12055

Tidball, K. G. 2012. Urgent biophilia: human-nature interactions and biological attractions in disaster resilience. Ecology and Society 17(2):5. http://dx.doi.org/10.5751/ES-04596-170205

Tooke, T. R., B. Klinkenberg, and N. C. Coops. 2010. A geographical approach to identifying vegetation-related environmental equity in Canadian cities. Environment and Planning B: Urban Analytics and City Science 37(6):1040-1056. http://dx.doi.org/10.1068/b36044

Tratalos, J., R. A. Fuller, K. L. Evans, R. G. Davies, S. E. Newson, J. J. D Greenwood, and K. J. Gaston. 2007. Bird densities are associated with household densities. Global Change Biology 13 (8):1685-1695. http://dx.doi.org/10.1111/j.1365-2486.2007.01390. $\underline{\mathrm{x}}$

Turner, W. R., T. Nakamura, and M. Dinetti. 2004. Global urbanization and the separation of humans from nature. Bioscience 54(6):585-590. http://dx.doi.org/10.1641/0006-3568 (2004)054[0585:GUATSO]2.0.CO:2

Ulrich, R. S., R. F. Simons, B. D. Losito, E. Fiorito, M. A. Miles, and M. Zelson. 1991. Stress recovery during exposure to natural and urban environments. Journal of Environmental Psychology 11 (3):201-230. http://dx.doi.org/10.1016/S0272-4944(05)80184-7

United Nations. 2011. World urbanization prospects: the 2011 revision. United Nations, New York, New York, USA.

van Heezik, Y., C. Freeman, S. Porter, and K. J. M. Dickinson. 2013. Garden size, householder knowledge, and socio-economic status influence plant and bird diversity at the scale of individual gardens. Ecosystems 16(8):1442-1454. http://dx.doi.org/10.1007/ $\underline{\text { s10021-013-9694-8 }}$

Vergnes, A., V. Pellissier, G. Lemperiere, C. Rollard, and P. Clergeau. 2014. Urban densification causes the decline of grounddwelling arthropods. Biodiversity and Conservation 23 (8):1859-1877. http://dx.doi.org/10.1007/s10531-014-0689-3

Villaseñor, N. R., A. I. T. Tulloch, D. A. Driscoll, P. Gibbons, and D. B. Lindenmayer. 2017. Compact development minimizes the impacts of urban growth on native mammals. Journal of Applied Ecology 54(3):794-804. http://dx.doi.org/10.1111/1365-2664.12800

Wen, M., X. Zhang, C. D. Harris, J. B. Holt, and J. B. Croft. 2013. Spatial disparities in the distribution of parks and green spaces in the USA. Annals of Behavioral Medicine 45(S):S18-S27. http:// dx.doi.org/10.1007/s12160-012-9426-X

Wilson, E. O. 1984. Biophilia. Harvard University Press, Cambridge, Massachusetts, USA. 